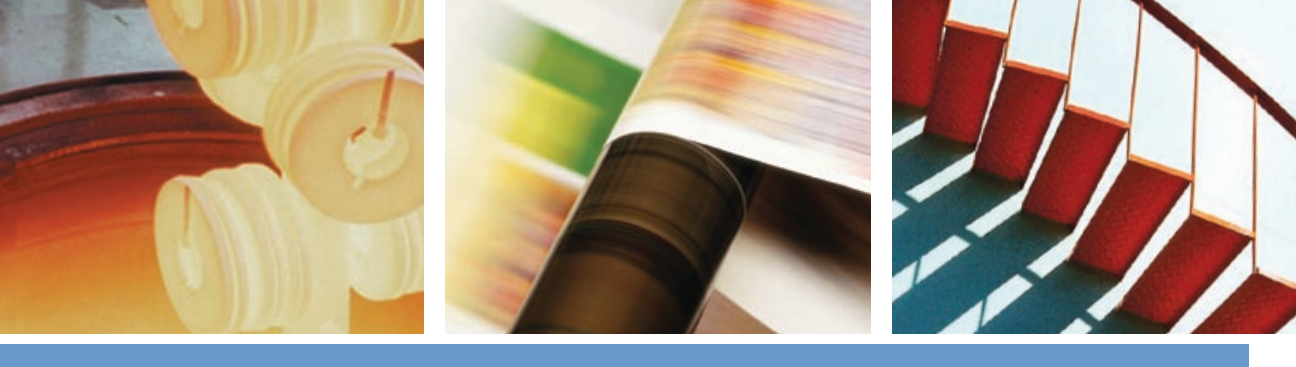

参与工业能源效率合作伙伴计划从现在开始节能
美国能源部与中国国家发展与改
革委员会之间的合作伙伴关系将
促进中国制造企业提高能源效率
和减少排放。改善中国大多数高
能耗工业中能源系统的性能将有
助于实现 “十一五” 规划中千家
企业节能减排目标。
合作伙伴关系借鉴美国政府针对
功经验。每个审计过的系统的平 均能源节约潜力可达 $8 \%-10 \%$ 或 200万美元（1470万元人民币）
通过 “节能从现在开始” 行动, 美国能源部提供一系列经过实际 检验并有助于中国企业达到2010 年能源强度降低20\%目标的方法、 软件工具和资源。

美国制造企业进行现场能源审计

的 “节能从现在开始” 行动的成

Participate in the Industrial Energy Efficiency Cooperative Partnership and Save Energy Now!
The cooperative partnership between the United States Department of
Energy (U.S. DOE) and the National
Development and Reform Commission
will promote energy efficiency and
emissions reductions in Chinese
manufacturing enterprises. Improving
the performance of energy systems in
China's most energy-intensive industries
will help meet the goals for the Top 1000 enterprises under the $11^{\text {th }}$ Five Year Plan.
The partnership is modeled after a successful U.S. government program for industry, Save Energy Now, which
provides onsite energy audits for U.S. manufacturing enterprises. Energy savings opportunities identified at each system audited to date averaged energy savings of $8 \%-10 \%$ or $\$ 2$ million USD (14.7 million RMB).
Through Save Energy Now, U.S. DOE offers a set of proven methods, software tools, and resources that can help China's enterprises reach energy intensity reduction targets of $20 \%$ by 2010 .

工㞦能源效率 合作伙伴

合作双方:

中华人民共和国

国家发展与改革委员会

资源节约和环境保护司

en.ndrc.gov.cn

与

美国

能源部

能源效率与可再生能源局, 工业技术项目

www.eere.energy.gov/industry/

saveenergynow

美国能源部能源效率与可再生能源局支持 能源效率和可再生能源技术方面的研发,

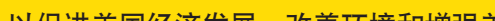

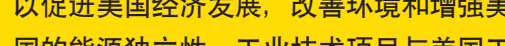

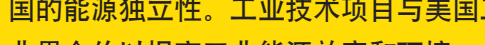
业界合作以提高工业能源效率和环 性能。

如需了解更多信息, 请联系

For More Information, Please Contact:

Amy Chiang

amy.chiang@ee.doe.gov

U.S. Department of Energy

Energy Efficiency and Renewable Energy

Efficiency Partnership

Industrial Technologies Program

Industrial Energy

A partnership between:

The People's Republic of China National Development and Reform Commission Department of Resource Conservation and Environment Protection

The United States of America

Department of Energy

Dffice of Energy Efficiency and Renewable

saveenergynow

The Office of Energy Efficiency and Renewable Energy supports research and development in energy efficiency and renewable energy technologies to improve the U.S. economy,

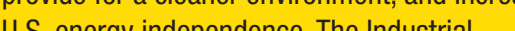
Technologies Program works with U.S ind to improve industrial energy efficiency and environmental performance.

Produced for the

U.S. Department of Energy,
Office of Energy Efficiency and Renewable Energy . a DOE National laboratory

DOE/G0-102008-2541, January 2008

Printed with renewable-source ink on paper containing at leas

$50 \%$ wastepaper, including 10\% postconsumer waste.
工业能源效率合作伙伴

促进中国制造企业提高能源效率和减少排放

\section{Industrial Energy Efficiency Cooperative Partnership}

Promoting energy efficiency and emissions reductions in Chinese manufacturing enterprises

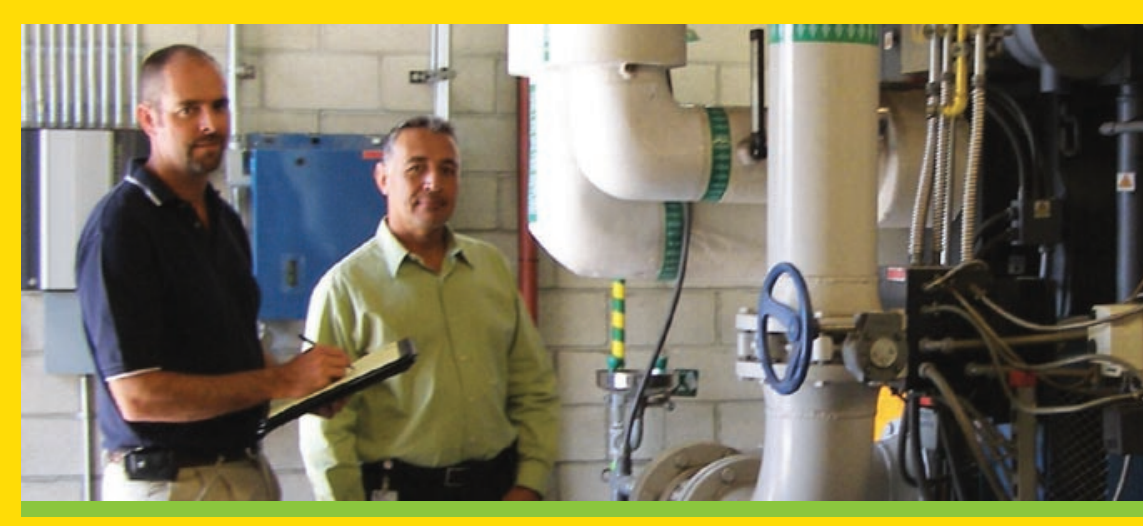

节能从现在开始

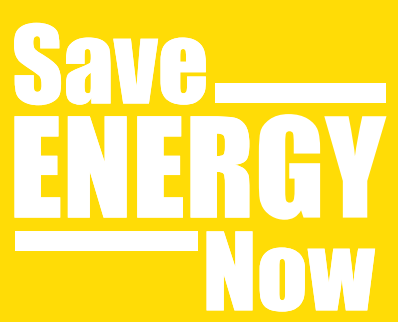




\section{能源审计确认能源节 约潜力}

合作伙伴关系的主要任务之一是在 钢铁、有色金属、石油与石化、 化工、采矿、建筑材料、纺织以及造 纸等行业中选定的大型高能耗中国制 造企业进行能源审计。

美国能源部专家将访问这些企业并进 行能源审计、确认能源节约潜力并对 如何采用新型能效技术提出建议。

\section{Energy Audits Identify Energy Savings Opportunities}

A key element of the partnership is energy audits at selected top energy-intensive Chinese manufacturing enterprises in iron, steel, non-ferrous metals, petroleum and petrochemicals, chemicals, mining, construction materials, textiles, and paper industries.

U.S. DOE Energy Experts will visit the enterprises to perform energy audits, identify energy savings opportunities, and make recommendations for new energyefficient technologies.

\section{能源审计过程概述}

\section{The following summarizes the audit process.}

\section{能源审计准备工作}

每家企业应该指定一名负责人与能源

专家进行合作。该负责人需要收集预 期要审计能源系统的相关信息与数 据。鼓励负责人对企业进行一次快速 能源分析 (Quick PEP )，相关信息可以 通过以下网址获得:

www.eere.energy.gov/industry/

bestpractices/quickpep_tool.html

企业应该成立一个由工程技术人员、 会计和决策人员组成的团队, 参与整 个审计过程并就如何有效实施审计提 供关键信息。此外, 鼓励企业从各个 行业协会、大学以及地方节能中心 等单位选择团队成员帮助实施审计工 作。

\section{Preparation for the Audit}

Each enterprise should prepare for the energy audit by assigning a lead person to interact and coordinate with the Energy Expert. The lead person will also collect pre-audit data and descriptive information about potential energy systems to be addressed. The lead is encouraged to complete a Quick PEP analysis of the enterprise, which may be found at: www.eere.energy.gov/industry/bestpractices/ quickpep tool.html.

The enterprise should assemble a team of engineers, technicians, accountants, and decision-makers to participate throughout the audit process and provide critical input on the strategy to implement audit findings. Additionally, the enterprise is encouraged to identify team members from industry associations, universities, and local energy centers who may contribute to a successful audit.

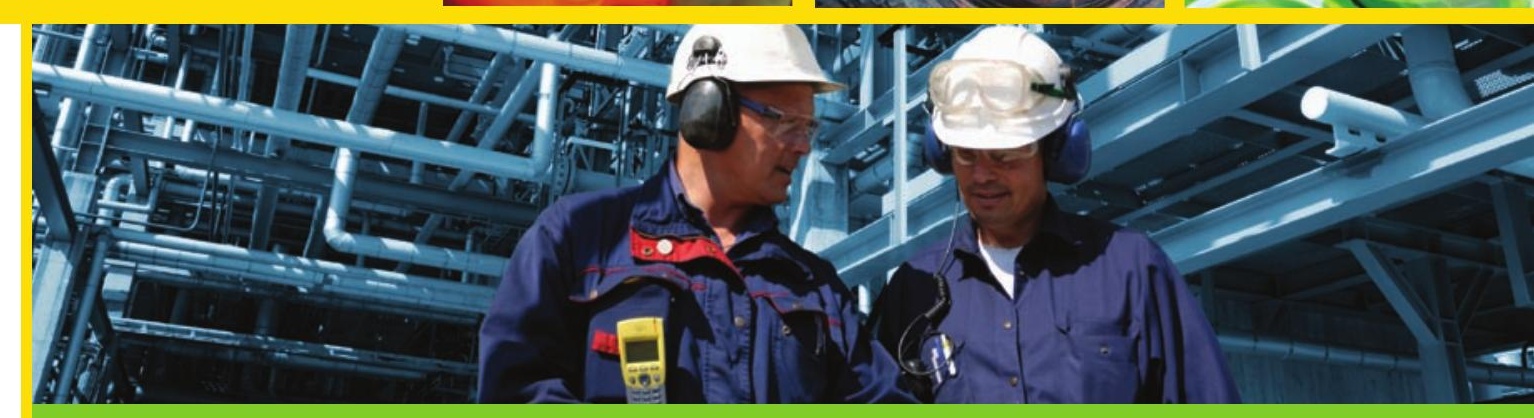

\section{系统方法}

审计将着重于压缩空气、工艺加热和蒸汽 等高能耗系统。针对这些系统进行性能优 化并达到显著节能的目的。

\section{能源专家}

能源专家可以熟练使用各种软件工具进行 能源审计以确定企业节能潜力。能源专家 均经过美国能源部软件工具使用认证, 同 时拥有丰富的工业实践经验。

\section{培训}

作为能源审计过程的重要内容, 能源专家 将示范包括各种美国能源部软件工具在内 的“节能从现在开始” 模型。相关软件工 具可以通过以下网址获得: www.eere.energy.gov/industry/ bestpractices/software.html。

\section{Systems Approach}

The audits will focus on energy-intensive systems, including compressed air, process heating, and steam. By targeting these systems, performance is optimized and significant energy is saved.

\section{Energy Experts}

Energy Experts are skilled in performing energy audits by using the software tools to identify energy savings opportunities. In addition to U.S. DOE certification in the software tools, Energy Experts have significant industrial experience.

\section{Training}

As a key component of the energy audit process, an Energy Expert will demonstrate the Save Energy Now model, which includes U.S. DOE software tools. The software tools are available online at: www.eere.energy.gov/ industry/bestpractices/software.html.

\section{第1天}

召开启动会议，对审计过程以及评估目 标能源系统所用方法进行简介, 企业安 全管理人员对有关安全问题进行讲解。 能源专家示范软件工具的使用并和团队 一起参观企业。

\section{第2天和第3天}

能源专家和审计团队确认所需数据。收 集与能源效率潜力有关的数据并输入软 件工具以量化节能潜力。能源专家和团 队进行讨论并就确认出的节能潜力达成 一致。

\section{第4天和第5天}

审计团队使用获得的数据就确认的潜力 对节约效果进一步做出估计。团队完成 节约潜力的软件分析工作并与企业技术 人员和决策人员讨论实施策略。能源专 家最终通过总结会议结束审计过程。

审计过程将美国能源部的系统方法引入企业 审计团队。通过采用系统方法，企业团队苛 以提出实现千家企业节能目标的计划。 as

\section{Day One}

The audit begins with a kick-off meeting, which provides an overview of the audit process, the approach to be used for assessing the targeted energy systems, and a safety briefing by the enterprise safety manager. The Energy Expert demonstrates the software tool to be applied and, with the team, tours the enterprise.

\section{Days Two and Three}

The Energy Expert and the audit team identify data collection needs. They collect data on potential energy efficiency opportunities, enter it into the software tool, and quantify energy savings opportunities. The Energy Expert and the team discuss and agree upon the opportunities identified.

\section{Days Four and Five}

The audit team uses the data to further develop savings estimates for the opportunities identified. The team completes the software analysis of the savings opportunities and discusses implementation strategies with enterprise technical staff and decision-makers. The Energy Expert completes the audit with a close-out meeting.

This audit process introduces U.S. DOE'S system approach to the enterprise audit team. By adopting the system approach, the enterprise team can establish a plan that will meet their Top 1000 energy savings goals - py 